\title{
Diamonds and diamondiferous eclogites of the Jericho kimberlite (Northern Canada)
}

\author{
A. De Stefano ${ }^{1}$, M.G. Kopylova ${ }^{1}$, P. Cartigny $^{2}$, V Afanasiev $^{3}$ \\ ${ }^{1}$ University of British Columbia, Department of Earth and Ocean Sciences, 6339 Stores Road, \\ Vancouver, BC, Canada \\ ${ }^{2}$ Laboratoire de Géochimie des Isotopes Stables, Université de Paris VII, Institut de Physique du Globe \\ et URA CNRS 1762, 4 Place Jussieu, 75251 Paris Cedex 05, France \\ ${ }^{3}$ Institute of Geology and Mineralogy, 3 Koptiuga st., Novosibirsk, 678170 Russia
}

\section{Introduction}

The study characterizes diamonds from the Jericho kimberlite (Northern Slave craton), their morphology, nitrogen content and aggregation state, carbon isotopic composition, and mineral inclusion chemistry. The vast majority of the diamonds are sourced from eclogites and the petrogenesis of the stones therefore can only be understood in conjunction with the eclogite formation processes. The study gains insights into the origin of Jericho eclogites and diamonds using trace element analyses of garnet and clinopyroxene. We also explore possible causes of the magnesian character of the Jericho diamondiferous eclogites. Detailed studies of secondary recrystallization in Jericho eclogites led us to conclude that a magnesian metasomatism may have played a role in the formation of eclogites and diamonds. The ultimate products of such metasomatism could be "websteritic" diamond assemblages sourced from magnesian eclogites.

\section{Diamonds}

We studied a suite of 208 diamonds with weights < 0.16 ct. Diamonds from Jericho are typically colourless and their dominant crystal habit is octahedral, with cubic, dodecahedral and macle diamonds covering respectively $6 \%, 4 \%$ and $3 \%$ of the population. The degree of resorption is low, with the majority of samples falling in classes 4 and 5 of McCallum's

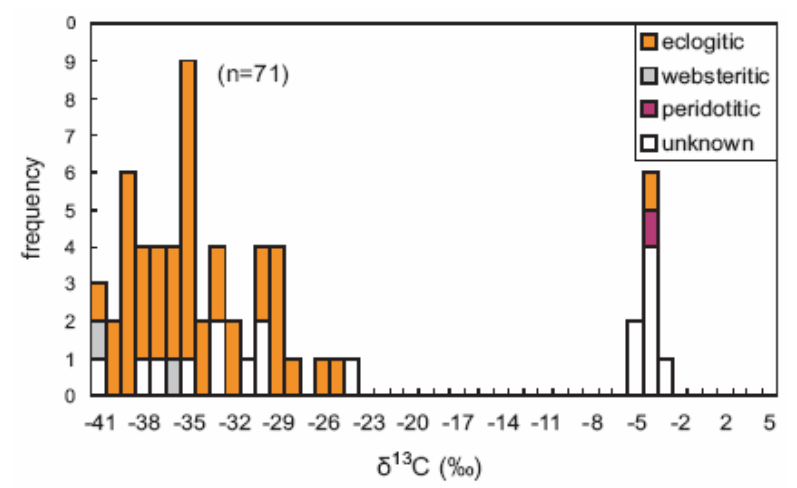

Fig. 1. Histogram showing the $\mathrm{C}$ isotopic composition of diamonds from Jericho. classification (McCallum et al. 1994). Nitrogen contents in the diamonds are low for $92 \%$ of the studied samples, with values ranging from below detection $(<20 \mathrm{ppm})$ to $750 \mathrm{ppm}$. Ninety-six per cent of diamonds are Type IaA, with paired $\mathrm{N}$ defects and less than $30 \%$ of fully aggregated $N$. The $\delta^{13} \mathrm{C}$ values of the diamonds show a roughly bimodal distribution, with a double peak at $-39 \%$, and $-35 \%$, and another small peak around -5\% (Fig. 1). Forty two diamonds with inclusions contained syngenetic inclusions of low $\mathrm{Cr}$ garnet (65 grains), low-Cr omphacite (8), orthopyroxene En 89 (1), olivine Fo93 (2), millerite
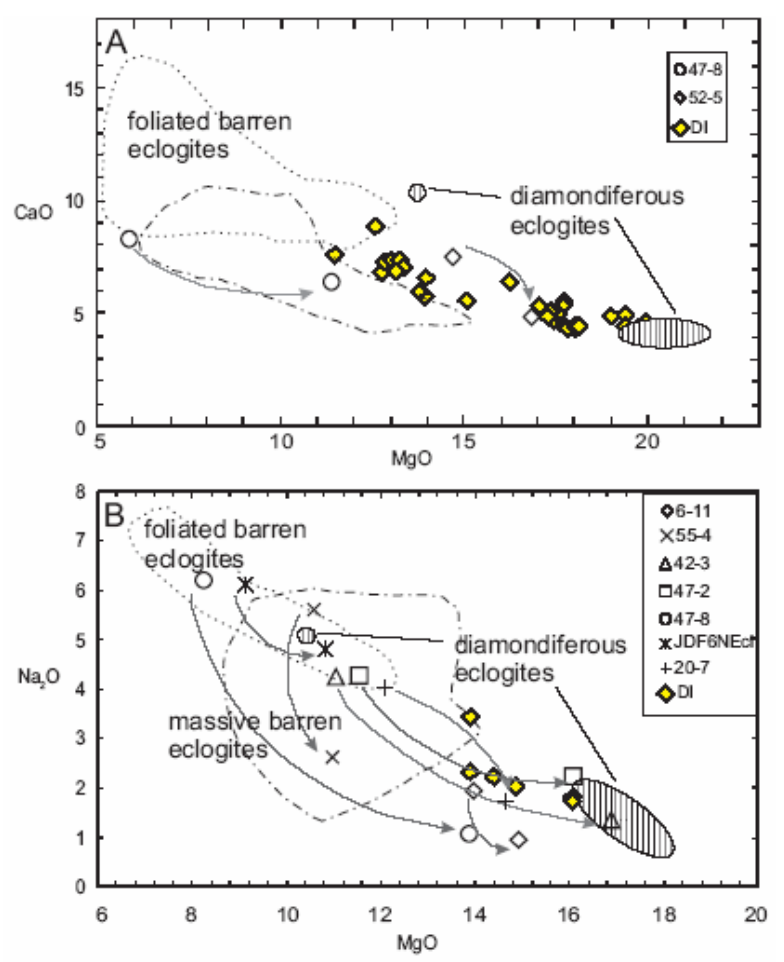

Fig. 2. A: $\mathrm{CaO}(\mathrm{wt} \%)$ versus $\mathrm{MgO}(\mathrm{wt} \%)$ plot for garnet $\mathrm{DI}$ (yellow diamonds) and garnets from Jericho eclogitic xenoliths (Kopylova et al. 1999a, Heaman et al. 2006). B: A plot of $\mathrm{Na}_{2} \mathrm{O}$ (wt\%) versus $\mathrm{MgO}(\mathrm{wt} \%$ ) for clinopyroxene DI (yellow diamonds) and Jericho eclogitic xenoliths. Open symbols indicate primary and secondary minerals in the eclogites. Arrows are drawn from the primary to the secondary mineral of the same sample. 
(2), hematite (1), diamond (1) and epigenetic inclusions of phlogopite (5), spinel (1) and ilmenite (1). The included diamonds belong to eclogitic (38 out of 42 stones), websteritic (3) and peridotitic (1) assemblages. Garnets and clinopyroxenes found as inclusions in diamonds (DI) form single compositional trends with respective minerals in Jericho diamondiferous xenoliths (Fig. 2). On the trends, DI minerals occupy less magnesian parts. Some of garnet DI with $\mathrm{Cr}_{2} \mathrm{O}_{3}>0.4 \mathrm{wt} \%$ that would be classified as "websteritic" based on their mineral chemistry are similar in composition to garnet found in magnesian Jericho eclogites. . We therefore suggest that elsewhere inclusions in diamonds classified as "websteritic" may come from $\mathrm{Mg}$-rich diamondiferous eclogites and their relative rarity among less magnesian diamondiferous eclogites explains a low abundance of "websteritic" DI with respect to "eclogitic".Garnet and clinopyroxene diamond inclusions display REE patterns similar to most DI worldwide, and 3 garnets and 4 clinopyroxenes show subtle negative $\mathrm{Eu}$ anomalies (Fig. 3).

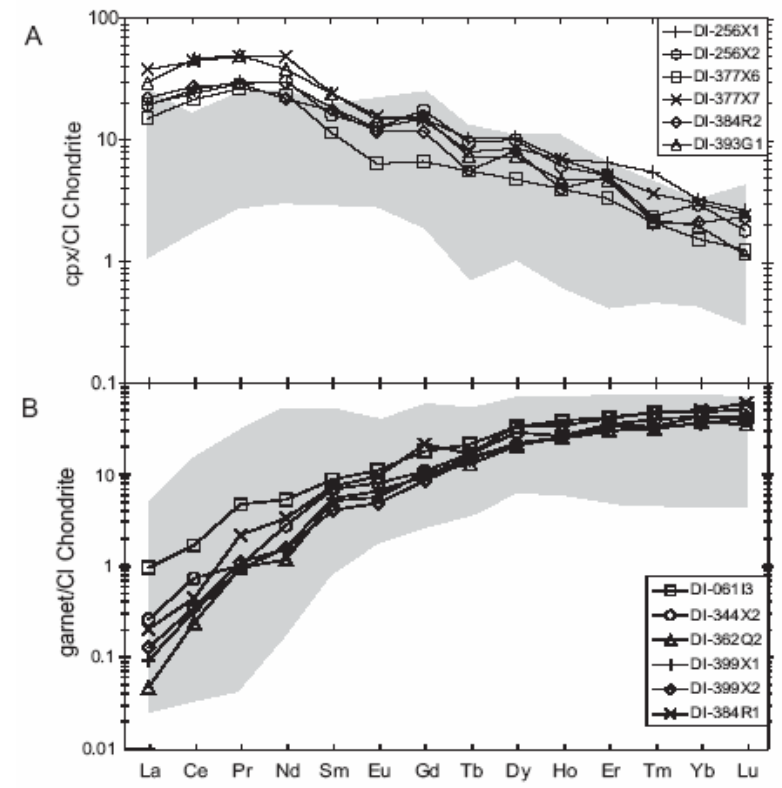

Fig. 3. Chondrite-normalized rare earth elements (REE) patterns for clinopyroxene (A) and garnet (B) inclusions in Jericho diamonds. Shaded fields are fields for worldwide DI (Stachel et al. 2004).

\section{Eclogites}

A suite of thirteen previously studied foliated and massive eclogites from the Jericho kimberlite was thoroughly investigated to check for zoning and recrystallization of primary minerals. Primary paragenesis of garnet, omphacite, olivine, orthopyroxene and kyanite in the Jericho eclogites underwent partial recrystallization and formation of secondary garnet $(0-13$ vol.\%) and diopside (0-30\%) around primary grains. Secondary garnet is richer in $\mathrm{Mg} \pm \mathrm{Ti}$-rich and poorer in $\mathrm{Ca}$. Secondary clinopyroxene is always enriched in $\mathrm{Ti}, \mathrm{Ca}$ and $\mathrm{Mg}$ compared to primary Na- and Al-rich clinopyroxene from the same sample. Several grains of primary and secondary clinopyroxene and garnet were analysed to estimate the magnitude of trace element compositional changes related to recrystallization (Fig. 4). Secondary clinopyroxene is richer in all trace elements than primary clinopyroxene repeating the shape of the spidergram at a higher level of concentrations. The only exception is $\mathrm{Ba}$, which is drastically more enriched in secondary grains. Secondary garnet is also richer than primary in all trace elements, but especially in $\mathrm{Ba}$, Hf and $\mathrm{Zr}$.

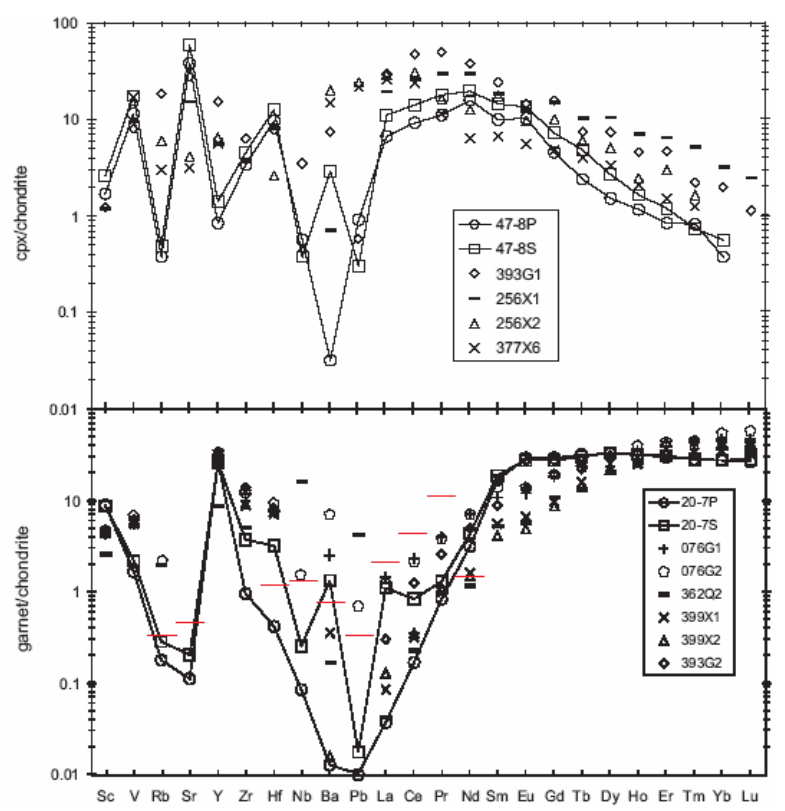

Fig. 4. Chondrite-normalized trace elements patterns for clinopyroxene (A) and garnet (B) from the Jericho DI (different symbols not connected by tie-lines) and selected primary (open circles connected by tie-lines) and secondary grains from eclogites (open squares connected by tie-lines). Red lines are MDLs.

\section{Origin of the diamondiferous paragenesis at Jericho}

The Jericho diamondiferous paragenesis is more magnesian than most other diamondiferous eclogites and eclogitic DI worldwide, and crystallizes diamonds with very light $\mathrm{C}\left(\delta^{13} \mathrm{C}=-5 \div-41 \%\right)$. These characteristics may have formed from subduction of a Mg-rich protolith or through magnesian metasomatism. Our preferred model involves magnesian metasomatism induced by a carbonate-silicate fluid rich in $\mathrm{Mg}, \mathrm{P}, \mathrm{Ti}, \mathrm{K}, \mathrm{REE}$ and $\mathrm{Ba}$.

This metasomatism is pervasive in Jericho eclogites and causes recrystallization and development of secondary minerals. The recrystallization brings mineral compositions in barren eclogites closer to respective mineral compositions in diamondiferous eclogites and DI. Some recrystallized clinopyroxene in barren eclogites is similar to clinopyroxene in diamondiferous eclogites.

The metasomatism may have also been involved in generation of diamonds and their DI. Three lines of evidence support this. Firstly, by low $\mathrm{Na}_{2} \mathrm{O}$ and high contents of $\mathrm{MgO}$, $\mathrm{Ba}$, HREEs, $\mathrm{La}$ and $\mathrm{Ce}$, DI clinopyroxene is closer to recrystallized secondary clinopyroxene than to primary clinopyroxene in 
eclogites. Secondly, DI garnet is characterized by elevated $\mathrm{Zr}$ and $\mathrm{Hf}$, typical of recrystallized eclogitic garnet. Finally, extremely low of the Jericho diamonds can be explained by metasomatism, but is difficult to account for by metamorphosed biogenic carbon. Worldwide, eclogitic diamonds formed by subduction have mostly mantle-like $\delta^{13} \mathrm{C}$ values at $\sim-5 \%$, extending to lower values of $-25 \%$, but do not reach $\delta^{13} \mathrm{C}$ values as low (-41\%) as observed at Jericho (e.g. De Corte et al. 1999). Since metasomatic growth of diamond from reduced fluids is known to shift $\delta^{13} \mathrm{C}$ to more negative values through isotopic fractionation (Galimov, 1991; Zheng, 1994; Thomassot et al. 2007), we propose that methane-rich metasomatism may have contributed toward diamond depletion in $\delta{ }^{13} \mathrm{C}$ beyond average eclogitic values.

An agent of mantle metasomatism can be a carbonate-silicate or a silicate fluid rich in $\mathrm{Mg}, \mathrm{P}, \mathrm{Ti}$, $\mathrm{K}$, REE and $\mathrm{Ba}$. Its carbonate-rich character may be implied by the $\mathrm{Ba}$ and $\mathrm{P}$ enrichment typical of carbonatite magmas, which is evident in the formation of metasomatic apatite and in the Ba enrichment of secondary clinopyroxene in Jericho eclogites. If occurrence of diamondiferous eclogites in the Jericho mantle could map the localization of metasomatism, it is restricted to $140-200 \mathrm{~km}$, as estimated from temperatures of garnet-clinopyroxene equilibrium (Ellis and Green, 1979) for 3 DI pairs and 16 diamondiferous eclogites. These depths coincide with the base of the eclogite-peridotite interleaving horizon and center around the lithosphere-asthenosphere boundary. Such localization of the metasomatism is not accidental. Firstly, metasomatic interaction is expected in the deepest eclogite lenses as ascending magnesian fluid equilibrated with peridotite first encounters a compositionally contrasting media, i.e. eclogites. Secondly, fluid should be abundant at the lithosphere-asthenosphere boundary, since magmatic activity in the $\mathrm{N}$ Slave mantle concentrates immediately below the base of the lithosphere (Kopylova et al. 1999b). Perhaps, areas of intensive mantle metasomatism similar to the metasomatism that formed N Slave diamonds can be traced by occurrences of highly magnesian eclogites and "websteritic" diamonds.

\section{References}

De Corte, K., Cartigny, P., Shatsky, V.S., De Paepe, P., Sobolev, N.V., Javoy, M., 1999. Characteristics of microdiamonds from UHPM rocks of the Kokchetav Massif (Kazakhstan). In: Dawson, J.B., and Nixon, P.H. (eds) Proceedings of the $7^{\text {th }}$ International Kimberlite Conference, Cape Town, Vol. 1,174-182

Ellis, D.J., and Green, D.H., 1979. An experimental study of the effect of $\mathrm{Ca}$ upon garnet-clinopyroxene $\mathrm{Fe}-\mathrm{Mg}$ exchange equilibria. Contributions to Mineralogy and Petrology 71:13-22.

Galimov, E.M., 1991. Isotope fractionation related to kimberlite magmatism and diamond formation. Geochimica et Cosmochimica Acta 55:1697-1708.
Heaman, L.M., Creaser, R.A., Cookenboo, H.O., Chacko, T., 2006. Multi-Stage Modification of the Northern Slave Mantle Lithosphere: Evidence from Zircon- and Diamond-Bearing Eclogite Xenoliths Entrained in Jericho Kimberlite, Canada. Journal of Petrology 47(4):821-858.

Kopylova, M.G., Russell, J.K., and Cookenboo, H.O. 1999a. Mapping the lithosphere beneath the North Central Slave Craton. In: Dawson JB and Nixon PH (eds) Proceedings of the $7^{\text {th }}$ International Kimberlite Conference, Cape Town, Vol. 1, 468-479

Kopylova, M.G., Russell, J.K., and Cookenboo, H.O., 1999 b. Petrology of peridotite and pyroxenite xenoliths from the Jericho kimberlite: implications for the thermal state of the mantle beneath the Slave craton, northern Canada. Journal of Petrology 40:79-104.

McCallum, M.E., Huntley, P.M., Falk, R.W., Otter, M.L., 1994. Morphological, resorption and etch feature trends of diamonds from kimberlite populations within the Colorado-Wyoming state line district, USA. In: Meyer H.O.A., and Leonardos, O. (eds) Proceedings of the $5^{\text {th }}$ international kimberlite conference, Brasilia, Brazil, Companhia de Pesquisa de Recursos Minerals, pp 7897.

Stachel, T., Aulbach, S., Brey, G.P., Harris, J.W., Leost, I., Tappert, R., Viljoen, K.S., 2004. The trace element composition of silicate inclusions in diamonds; a review. Lithos 77(1-4):1-19.

Thomassot, E., Cartigny, P., Harris, J.W., and Viljoen, K.S., 2007. Methane-related diamond crystallization in the Earth's mantle: Stable isotope evidences from a single diamond-bearing xenolith: Earth and Planetary Science Letters 257: 362-371.

Zheng, Y.F., 1994. Mantle degassing and diamond genesis: A carbon isotope prospective. Chinese Journal of Geochemistry 13(4):305-316. 